\title{
Embryonic and early juvenile development in the Silurian basal nautilid Peismoceras Hyatt, 1894
}

\author{
Štěpán Manda ${ }^{1}$ (1) $\cdot$ Vojtěch Turek ${ }^{2}$
}

Received: 24 September 2018 / Accepted: 13 March 2019/Published online: 15 May 2019

(C) Akademie der Naturwissenschaften Schweiz (SCNAT) 2019

\begin{abstract}
The family Lechritrochoceratidae Flower, 1950 includes the earliest cephalopods acquiring a lateral pair of retractor muscles-a diagnostic character of the Nautilida. The embryonic shell of Silurian lechritrochoceratids is minute, with a diameter of 2-4 mm, a length of 4.5-7.5 mm and consists of three growth stages: (1) elliptical, dorsoventrally elongated and flattened cicatrix with a central bar, (2) a short, rapidly expanding shell part and (3) a gradually expanding, very slightly curved shell. The sculpture consists of longitudinal lirae, and faintly distinct growth lines or ridges. A ventral lobe formed by ridges corresponds in its course to post-hatching ribs. This lobe indicates the early development of the hyponome in the egg capsule. The hatching is indicated by the appearance of ribs and sometimes also by a change in shell curvature. The juvenile stage is characterised by the prolongation of the body chamber, a change in the shape of the cross section, increasing expansion rate, and by a deepening of the hyponomic sinus. The juveniles were probably demersal with the aperture oriented more or less towards the sea floor. The dorsoventrally elongated cicatrix with a central bar and a depression corresponding to the caecum position and the appearance of longitudinal lirae near the cicatrix margin support systematic position of the lechritrochoceratids among the Nautilida. The hemispherical apex and the very slightly curved embryonic shell, ribbed juvenile shell and narrow annular elevation around the body chamber base, however, call for the definition of a new suborder Lechritrochoceratina.
\end{abstract}

Keywords Nautilida $\cdot$ Embryonic shell development $\cdot$ Juvenile autecology $\cdot$ Silurian

\section{Introduction}

The family Lechritrochoceratidae Flower, 1950 (latest Ordovician-Late Devonian) includes the earliest nautiloids possessing important characters of the Nautilida, such as a lateral pair of retractors and a thin, tubular subcentral siphuncle. Additional features frequently occurring in Late Palaeozoic nautilids - the development of a subquadratic shell cross section and a tendency to form ventrolateral nodes-are also known in lechritrochoceratids (Dzik 1984;

Editorial Handling: C. Klug.

Štěpán Manda

stepan.manda@geology.cz

1 Odbor regionální geologie sedimentárních formací, Česká geologická služba, Klárov 3, P.O. Box 85, 11821 Praha 1, Czech Republic

2 Národní muzeum, paleontologické oddělení, Václavské náměstí 68, 11579 Praha 1, Czech Republic
Dzik and Korn 1992). The lechritrochoceratids were originally placed in the order Barrandeocerida (Flower and Kummel 1950; Sweet 1964). By contrast, the Devonian Rutoceratidae were considered to be the earliest nautilids (Kummel 1964). However, based on the embryonic development, the structure of intrasiphonal deposits in earlier taxa and the presence of multiple paired muscle scars, the family Rutoceratoidea Hyatt, 1884 was moved to the order Oncocerida Flower, 1950 (Turek 2007; Manda and Turek 2011).

The shell of lechritrochoceratids is exogastric, tightly to loosely coiled, or only moderately curved. The shell in the earliest lechritrochoceratid Bickmorites Foerste, 1925 (latest Ordovician) is planispiral and the whorls are not in contact (Flower and Kummel 1950; Stearn 1956). The mode of shell coiling is less uniform than in later nautilids; well-developed shell uncoiling of the last whorl is a character common in Early Palaeozoic coiled cephalopods (Flower 1955; Manda and Turek 2011), not occurring in younger nautilids. All lechritrochoceratids have well- 
developed ribs. In some derived taxa, the ribs are reduced in later ontogenetic stages and may be transformed into nodes (Turek 1975). The shell colouration described in two species of Peismoceras consists of narrow zigzag bands (Turek and Manda 2010, 2011), a colour pattern also known in Late Palaeozoic Nautilida (Kobluk and Mapes 1989). The shape of the cross section often moderately changes throughout ontogeny; this feature is well expressed in the Devonian nautilid Centroceras Hyatt, 1884 and Late Palaeozoic nautilids (e.g. Kummel 1964).

Previously, the embryonic shell of four lechritrochoceratid species has been described, coming from the Ludlow Series of Central Bohemia and Gotland, where each taxon is represented by a single specimen (Turek 1975, 2010). The taxonomic assignment of one of them is questioned in this paper. The length of the embryonic shell in lechritrochoceratids ranges from 4.5 to $11 \mathrm{~mm}$, and the diameter of the aperture ranges from 2 to $3 \mathrm{~mm}$ (Turek 2010). The embryonic shell is very slightly curved with prominent longitudinal lirae and the hatching point is interpreted to occur at the onset of prominent transverse ribs (Turek 2010). Turek (1975) argued for a planktic habit of freshly hatched juveniles. Mature lechritrochoceratids were probably demersal swimmers with well-developed hyponome and eyes (Turek 1975).

The genus Peismoceras Hyatt, 1894 (early Wenlock to latest Př́dolí) represents one of the best-known representatives of the family Lechritrochoceratidae (Turek 1976, 2010; Turek and Manda 2010). The embryonic shell has so far been described in the species $P$. pulchrum (Barrande, 1865) from the Silurian rocks of Central Bohemia, Czech Republic (Turek 2010). Here, we describe the early ontogenetic development in two further species of Peismoceras from Central Bohemia-P. asperum (Barrande, 1865) and $P$. scharyi sp. nov. The cicatrix and healed injuries on the juvenile shells are described in lechritrochoceratids for the first time.

\section{Geological setting}

The Palaeozoic of Central Bohemia is a part of the historically defined Barrandian area, which consists of Proterozoic and Lower Palaeozoic rocks (Teplá-Barrandian Unit, Bohemian Massif). The Silurian rocks crop out in the Prague Synform, a structure formed during the Variscan Orogeny. These rocks are a part of a marine sedimentary succession ranging from the lowermost Ordovician to the Middle Devonian. The sedimentary succession is an erosional remnant of a rift-like structure infill named the Prague Basin (Kř́žz 1998). From the Early Ordovician to the Middle Devonian, the Teplá-Barrandian Unit was part of a peri-Gondwanan terrain considered as the independent microplate Perunica (see Torsvik and Cocks 2013). Alternatively, it may be considered as a part of the Armorican terrain assemblage or HUN-superterrain, which was an integral part of Gondwana until the Late Silurian (Stampfli et al. 2002; Robardet 2003; Raumer and Stampfli 2008).

Five lithostratigraphic units were established in the Silurian strata of the Prague Synform (Kříž 1998). The material studied here comes from the upper Motol and lower Kopanina formations, which consist of volcanicsedimentary and offshore shale facies. The boundary between these formations corresponds to the base of the Ludlow Series.

The proximal volcanic-sedimentary facies consists of effusive basalts, agglomerates, hyaloclastics and coarsegrained pyroclastics, sometimes containing volcanic bombs and tuffites (for summary see Kř́̌̌ 1991, 1998). Skeletal limestones, restricted to periods of ceased volcanic activity, usually form thin local beds; more continuous carbonate sedimentation is geographically and temporally limited. Brachiopods, crinoids, corals and trilobites are most abundant in the limestones, along with locally common bryozoans and stromatoporoids.

The distal volcanic-sedimentary facies deposited on slopes of the volcanic highs consists of alternating tuffites, hyaloclastics and thin effusive basalts, platy skeletal limestones with a rich cephalopod/bivalve or trilobite dominated fauna (Havlíček 1995; Kř́ž 1998), tuffitic shales and occasional black shales (Kříž et al. 1993). Intraformational conglomerates and slumped beds are common. Laminated shales predominate in the more distal settings.

Offshore shales of the Motol Formation were deposited away from the volcanic centres beyond the direct influence of local volcanic events. Black laminated calcareous graptolite rich shales prevail, sometimes containing a remarkable tuffitic admixture. Muddy limestone nodules rich in pyrite are usually present. Local slump beds up to a few tens of centimetres are occasionally developed.

Specimens of the cephalopod Peismoceras scharyi sp. nov. studied here come from the upper parts of the Motol Formation. A juvenile specimen collected by Barrande (1877) was found at the locality Kozel (name derived from "V Kozle Rock"), which represents a cumulative name for several locations SW of the Hostim Village in the area between Loděnice Brook and Berounka River. In this area, Wenlock volcanic rocks crop out and are overlain by $40 \mathrm{~m}$ thick upper Wenlock limestones of proximal volcanicsedimentary facies attributed to the "facies of Kozel" or the Kozel Member of the Motol Formation (Kříz 1992). Barrandés specimen is preserved in a yellow, weathered limestone that lithologically corresponds to the lowermost limestone succession, just above the volcano-clastics (Křriž 1992). This part of the succession is stratigraphically younger than the $C$. lundgreni Biozone and older than the 
base of the Ludlow Series (Kř́žz 1992). Some brachiopods indicate $P$. parvus Biozone in age (Havlíček 1995). Other specimens of $P$. scharyi sp. nov. came from the Braník locality (= Praha-Braník area). There, Silurian rocks crop out in a synform closure on the right side of the Vltava River in the western slope of the Školní Hill. Cephalopods are preserved in limestone nodules or as slightly flattened shells filled by limestone embedded by shale (see Turek 1987). Limestone infillings of cephalopod body chambers contain the fauna of the Decoroproetus-Ravozetina Community (Havlíček and Štorch 1990), indicating the age of P. parvus Biozone (Kř́ž et al. 1993). The exact site of the collecting locality is unknown, but the lithology and the mode of preservation of specimens studied correspond to a $70 \mathrm{~cm}$-thick bed (no. 3) exposed in the Braník section (no. 764), P. parvus Biozone, distal volcanic-sedimentary facies (Kříž 1992; Kř́rž et al. 1993). A single specimen of $P$. scharyi sp. nov. was found during a new field research in a limestone nodule embedded by shales of the $P$. parvus Biozone in the Kosov Quarry, section 767 (Kř́rž 1992).

The studied specimens of $P$. asperum were collected in the Praha-Řeporyje road cut section. The section-a branch from the street K Holému vrchu-is located $560 \mathrm{~m}$ to the SW from the church in Praha-Řeporyje (Bouček 1937), coordinates $50.0283503 \mathrm{~N}, 14.3178481 \mathrm{E}$. The road cut exposing the lowermost part of the Kopanina Formation (Ludlow Series) consists of basalt effusions overlain by an about $15 \mathrm{~m}$-thick succession of shales and tuffites intercalated with platy limestones (distal volcanic-sedimentary facies). A bed of skeletal limestone, about $25 \mathrm{~cm}$ thick, embedded by tuffaceous shales and platy limestones yielded the studied specimens of $P$. asperum. The bed contains abundant tabulate corals preserved in living position, encrinurid trilobites, gastropods and cephalopods; brachiopods and bivalves are less common. The graptolite Saetograptus chimaera occurring in the underlying shale indicates a scanicus-chimera Biozone age; the trilobite Cromus orizaba (Šnajdr, 1983) suggests the lower-middle part of the biozone (Kř́žz et al. 1993).

\section{Materials and methods}

The studied specimens are housed in the collection of the National Museum, Prague (prefix NM-L), Natural History Museum, London (prefix C), Natural History Museum, Brussels (prefix a) and the collection of J. M. Schary stored at the Museum of Comparative Zoology, Harvard (prefix MCZ).

The term 'juvenile stage' is used for the post-hatching developmental phase in which the shell still did not acquire the habit of sub-adults, i.e. in the case of Peismoceras, the growth phase of the shell between the embryonic shell and the point in which the shell completed the first whorl. The term 'sub-adult' defines the stage between the juvenile and the adult stages. The stage commences in full attainment of the morphological features used to define the species (Young and Harman 1988). The terms dextral and sinistral trochoceroid are used here in accordance with Flower (1964). Graptolite biozones are used as defined by Štorch (1994) and Štorch et al. (2014).

\section{Description of embryonic and juvenile growth stages}

Peismoceras scharyi sp. nov. (Fig. 1a-f)

For the full systematic palaeontology of this new species, see the "Taxonomic appendix" below.

Material One juvenile specimen MCZ 165412 with preserved embryonic stage from upper Wenlock strata, locality Kozel.

Description The specimen MCZ 165412 is a shell about $18 \mathrm{~mm}$ long with a slightly damaged apertural margin laterally; the maximum whorl height is $5.9 \mathrm{~mm}$ (Fig. 1). The shell wall is preserved around the whole circumference of the specimen; a fine sculpture is visible on the left side. The cross section is circular, close to the aperture it becomes slightly compressed.

The most apical part of the shell forms an almost smooth, flat elliptical field (cicatrix) with a dorsoventral diameter of $1.5 \mathrm{~mm}$ and a maximum width of $1.3 \mathrm{~mm}$. A small and very shallow depression is present close to the dorsal margin of the cicatrix (Fig. 1g, h). A shallow and narrow groove surrounded by an elevated zone is visible at the margin of the central bar (Fig. 1i, j). The dorsoventral length of the central bar corresponds to that of the cicatrix, but its width $(0.6 \mathrm{~mm})$ is about half as wide. Longitudinal lirae are present at the margin of the cicatrix (Fig. 1e, f).

After the cicatrix the shell rapidly expands, hemispherical; the dorsum is more curved than the venter. The length of this rapidly expanding part is $2.2 \mathrm{~mm}$. The expansion angle is about $30^{\circ}$, the flanks diverge at an angle of about $47^{\circ}$; the expansion rate decreases again where the shell is $3.2 \mathrm{~mm}$ high. The sculpture consists of longitudinal lirae. Seventeen lirae are present on the right side; the distance between individual lirae is variable. Five mid-lateral lirae are about two times higher than the adjacent ones and wider interspaces between the lirae also appear mid-ventrally and mid-dorsally. The ventrolateral longitudinal lirae are slightly vaulted towards the venter.

The rapidly expanding growth stage is followed by a nearly straight, slowly expanding shell part, which is about $5.4 \mathrm{~mm}$ long. The radial lirae extending from the apex are 
straight, the distance between individual lirae increases and the lirae become less distinct. The apical angle is $5^{\circ}$ at this position.

A shell constriction appears at the shell diameter of $3.8 \mathrm{~mm}$ and $7.5 \mathrm{~mm}$ from the apex. In the following growth stage, the shell becomes curved, moderately expanding with ten regularly spaced, well-developed transverse ribs. The ratio between the whorl height measured in the middle between adjacent ribs and the distance between ribs is between 3 and 3.7. The ribs are more steeply inclined adapically than adaperturally. They are straight and oblique with a shallow ventral sinus. The angle of expansion increases during ontogeny from $7^{\circ}$ to $12^{\circ}$. The first three ribs display fine longitudinal lirae; in later stages, they appear as a fine reticulate ornament.

\section{Peismoceras asperum (Barrande, 1865)}

Material Four juvenile specimens NM-L 46908-46911 (Fig. 2) were from the Praha-Řeporyje road cut section. Juveniles co-occur with specimen NM-L 46912, which preserves one-third of the last whorl of an adult individual. The specimen shows a straight diverging last whorl, an adapertural shell without ribs, flattened flanks
Fig. 2 Embryonic and juvenile shell of Peismoceras asperum (Barrande, 1865), Ludlow, Gorstian, lower scanicus-chimaera Biozone, Kopanina Formation, Bohemia, Praha-Řeporyje, road cut section. Scale bar $1 \mathrm{~mm}$. a, g NM-L 46909, lateral view, early shell (a) and complete shell (g), dotted line indicates partly broken off part of phragmocone with calcite infilling. b, d NM-L 46911 ventral and lateral views. c, f NM-L 46908, lateral view, early shell (c) and complete shell (g). e NM-L 46910, lateral view. Scale bars: a, c $(1 \mathrm{~mm}), \mathbf{b}, \mathbf{d}-\mathbf{g}(5 \mathrm{~mm})$. ar anomalous rib, $f w$ end of first whorl on dorsal side, $g r$ growth ridges, $h i$ healed shell injury, ill intercalation of longitudinal lirae, $s$ siphuncle; for others abbreviations see Fig. 1

and a subquadrate cross section-all are diagnostic characters of P. asperum (Barrande, 1865); see Fig. 3.

Description Specimen NM-L 46908 (Fig. 2c, f) is an almost complete shell with a ventrally slightly damaged aperture; the whorl reaches about $270^{\circ}$. The apical part of the phragmocone preserves the external shell, while the remaining part of the phragmocone and the body chamber are only preserved as an internal mould. The maximum shell diameter is $17.1 \mathrm{~mm}$ and the whorl height is $5.6 \mathrm{~mm}$. The apical part (Fig. 2c) is hemispherical with the venter being more convex than the dorsum; at a whorl height of

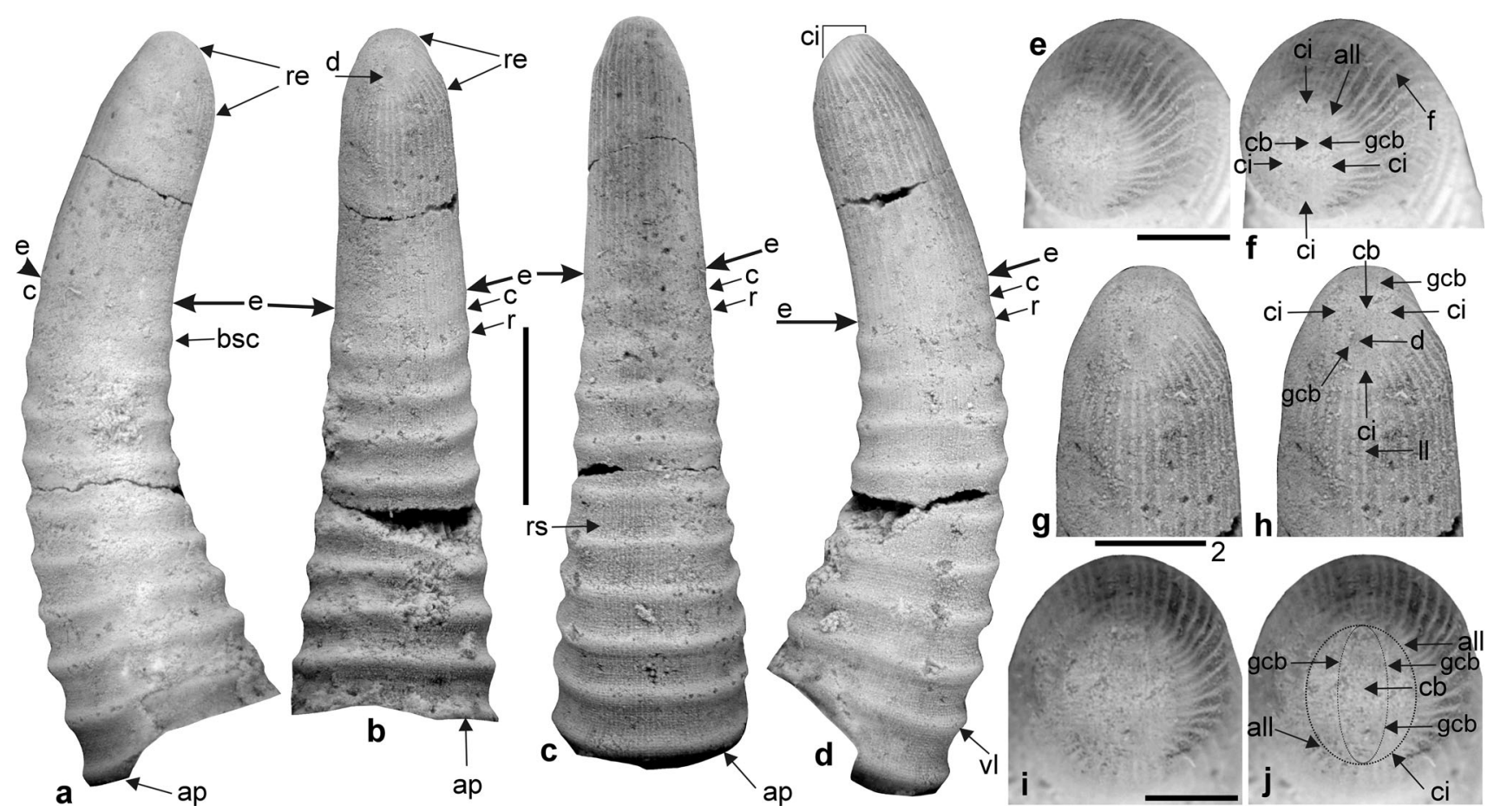

Fig. 1 Early juvenile specimen of Peismoceras scharyi sp. nov., MCZ 165412 (figured by Barrande 1877, pl. 511, figs. 11-14), Wenlock, Homerian, P. parvus Biozone, Motol Formation, Beroun, Kozel locality; right lateral (a), dorsal (b), ventral (c) and left lateral views (d), detail of apex $(\mathbf{e}, \mathbf{f}, \mathbf{i}, \mathbf{j})$ and dorsal part of the apex $(\mathbf{g}, \mathbf{h})$. Dotted lines in $\mathbf{j}$ indicate cicatrix area with central bar inside. Scale bars: $5 \mathrm{~mm}(\mathbf{a}-\mathbf{d}), 2 \mathrm{~mm}(\mathbf{g}, \mathbf{h}), 1 \mathrm{~mm}(\mathbf{e}, \mathbf{f}, \mathbf{i}, \mathbf{j})$. ap aperture, all appearance of longitudinal lirae, bsc breaks in shell curvature, $c$ constriction, $c b$ central bar, arrow indicates centre of the central bar; $c i$ cicatrix, arrows indicate margin of the cicatrix area, $d$ depression in cicatrix area, $e$ end of embryonic shell indicated by change in sculpture and appearance of the first rib, $f$ flexure in longitudinal lirae near apex, $g c b$ groove bordering central bar, $r$ rib, $r e$ rapidly expanding apical part of the shell, $r s$ reticulate sculpture, $v l$ ventral lobe of ridges/ribs (hyponomic sinus) 


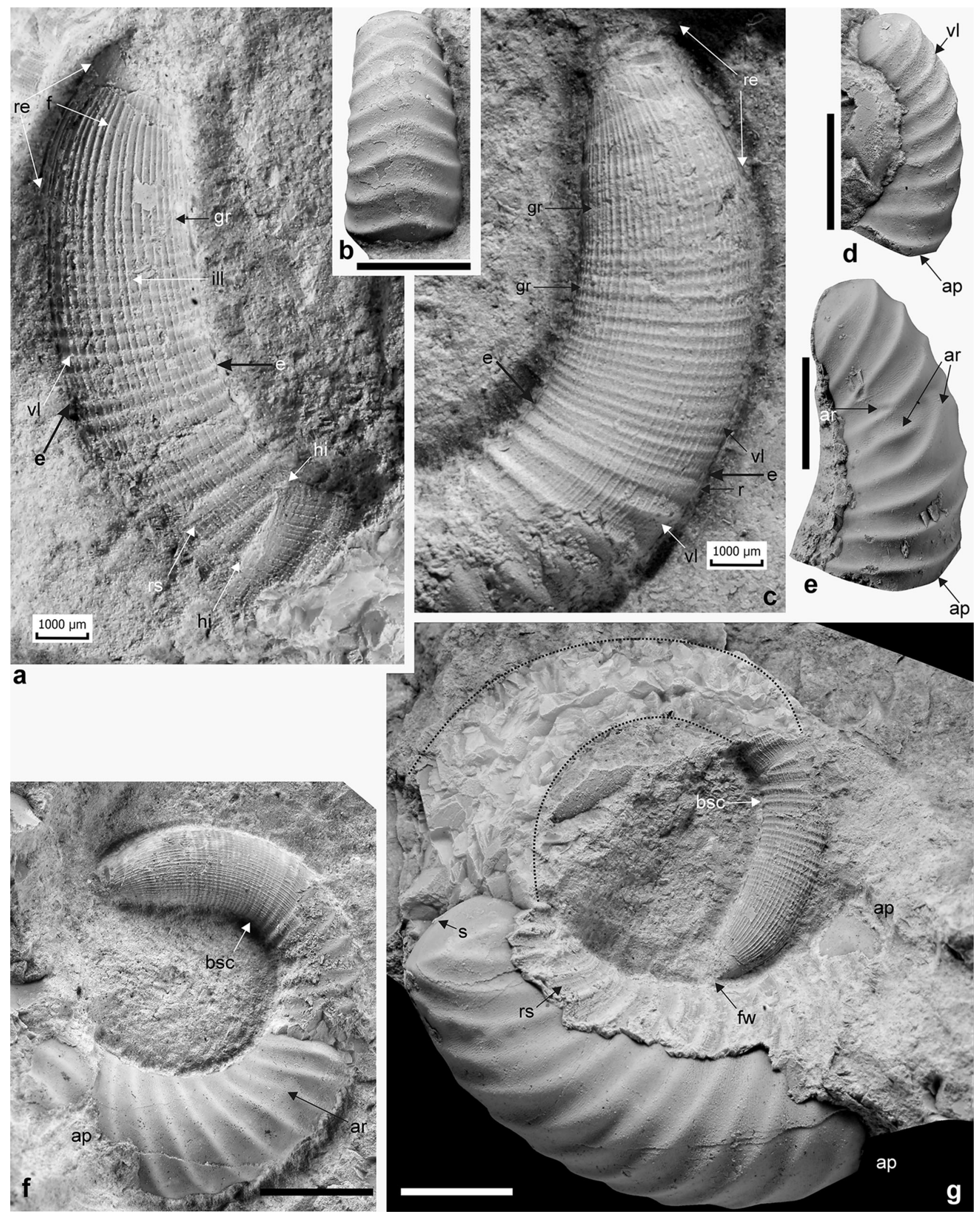




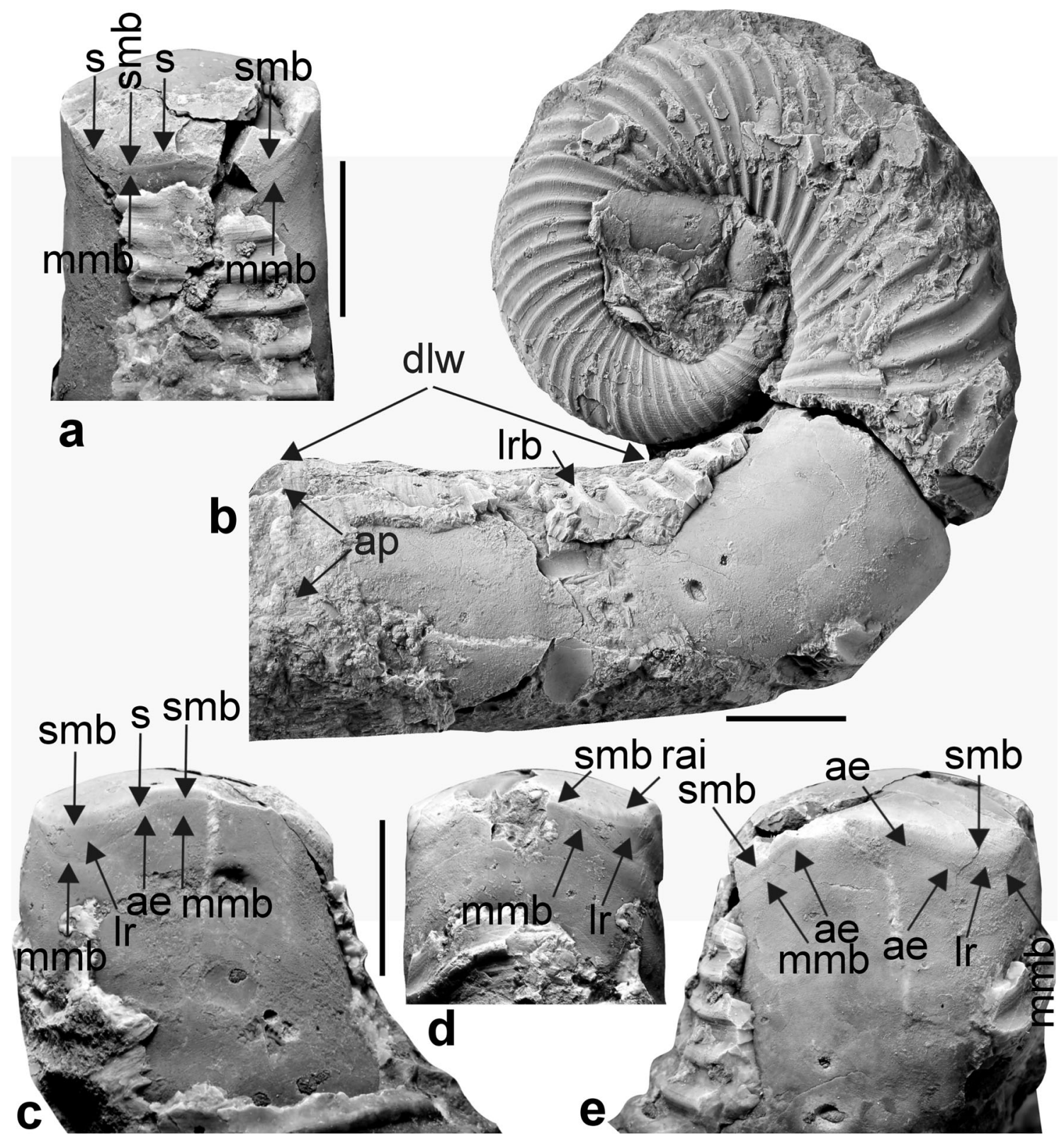

Fig. 3 Peismoceras asperum (Barrande, 1865), lectotype (SD, here) NM-L 7918 (Barrande 1865, pl. 16, figs 8-11), Ludlow, Gorstian, lower scanicus-chimaera Biozone, Kopanina Formation, Bohemia, Praha-Malá Chuchle, Vyskočilka locality (for location see Manda and Kříž 2007); lateral view (b) and details of body chamber base showing annular elevation with laterally situated attachment area of a pair of retractor muscles and imprints of radial septal arteries known

$3.1 \mathrm{~mm}$, the expansion rate decreases. The length of the rapidly expanding stage is $3 \mathrm{~mm}$. Radial lirae appear close to the the tip of the apex. Additional lirae appear slightly later near the apex. At a whorl height exceeding $3.1 \mathrm{~mm}$, the slowly expanding shell is slightly curved. The surface is ornamented with longitudinal lirae throughout later ontogeny. The distance between two adjacent lirae varies between 0.09 and $0.17 \mathrm{~mm}$ (measured directly in front of in nautilids (see Deecke 1913; Klug et al. 2008): dorsal (a), right lateral (c), ventral (d) and left lateral (e) views. Scale bar $1 \mathrm{~cm}$. ae annular elevation, ap aperture, $d l w$ divergent last whorl, $l r$ lateral retractor muscle scars, $l r b$ last rib, $m m b$ mantle myoadhesive band, rai radial arteries imprints on septum, $s$ suture line, smb septal myoadhesive band

the first rib). Fine growth lines appear simultaneously with the decrease in expansion rate close to the apex. Distinct transverse ridges appear at a whorl height of $3.4 \mathrm{~mm}$. The ridges are straight and oblique with a shallow ventral sinus. Eighteen ridges occur prior to the first rib and, together with the longitudinal lirae, they form a distinct reticulate ornament. The distance of growth lines and lirae is close to each other, or more frequently, the distance of adjacent 
growth lines is higher (up to two times). About 27 longitudinal lirae are developed just before the appearance of the first rib. The first ribs appear at $7.5 \mathrm{~mm}$ from the apical end and at a whorl height of $3.5 \mathrm{~mm}$, coinciding also with a change in coiling. The distance between the ribs is about two times higher than the distance between the ridges preceding the first rib. The first rib has the shape of a slightly elevated, narrow interspace between growth lines. The following ribs are well developed and sinusoidal in shaped. On the top of the second rib, a growth line is discernible, which is missing on the third rib (the following six ribs on the phragmocone lack external shell remains). The growth lines diverge from the ribs and the ventral sinus is better developed on the ribs. The ratio between whorl height (measured in the middle between adjacent ribs) and the rib distance is between 4.2 and $5.8 \mathrm{~mm}$. The body chamber represents about $115^{\circ}$ of the whorl. Nine ribs are present on the body chamber. Between the second and fifth rib on the body chamber, a mid-laterally elevated zone is evident; the third and fourth rib are slightly bent adapically and cross the longitudinal elevation. The irregular course of ribs and the elevated longitudinal zone indicates a healed injury of the shell.

The specimen NM L 46909 (Fig. 2b, g) is a damaged, almost complete shell slightly exceeding one whorl $\left(410^{\circ}\right)$. About two-thirds of the phragmocone are broken, thereby revealing the calcite infill of the phragmocone. The external shell is preserved at the early ontogenetic stage and the dorsal part of the body chamber. The maximum shell diameter is $23.1 \mathrm{~mm}$, the maximum whorl height is $8.9 \mathrm{~mm}$ and the maximum umbilical width is $9.5 \mathrm{~mm}$. The apical part of the shell is dorsally broken off and the thin shell wall is exfoliated (Fig. 2a). In later growth (at a length of about $2.3 \mathrm{~mm}$ ), the shell expands rapidly and the dorsum is more curved than the venter. Twenty longitudinal lirae occur laterally, curving slightly towards the venter. At a shell diameter of $2.7 \mathrm{~mm}$, the expansion rate decreases and fine transverse, straight and oblique ridges forming a shallow ventral sinus appear (Fig. 2a). The longitudinal lirae form a reticulate pattern in combination with the ridges. The distance between adjacent lirae is occasionally equal to the distance between neighbouring ridges, but usually the distance between two lirae is lower than that. Additional, more weakly developed lirae appear during shell growth. The first rib appears at a shell diameter of $2.9 \mathrm{~mm}$ (the shell length is $6.6 \mathrm{~mm}$ ) and the dorum is more curved than the venter. Eight ribs are preserved; they are straight and oblique to the coiling axis. The distance between ribs is higher than in the preceding ridges. A reticulate sculpture is present on the eighth rib. Nine ribs are preserved and their development ends at a point where the shell is damaged laterally. The repaired shell is preserved only in a small part, visible as irregular longitudinal lirae. A new rib appears dorsally after the shell injury and just prior to the damaged part of the phragmocone. Thirteen ribs are developed on the body chamber, which comprises $140^{\circ}$ of the whorl. The ribs are transverse with a broad ventral sinus (hyponomic sinus).

The third specimen NM L 46911 (Fig. 2b, d) is an internal mould of a body chamber with a maximum height of $3.9 \mathrm{~mm}$ and a length of $9.5 \mathrm{~mm}$. The hyponomic sinus is V-shaped and well developed; the ratio between sinus width and depth is between 3.7 and 4.1. The last septum has a maximum depth at the siphuncle position. The siphuncle is thin and in a central position. Nine ribs are developed. The body chamber reaches about $115^{\circ}$ of the whorl.

The fourth specimen NM-L 46910 (Fig. 2e) is an internal mould of the body chamber of a juvenile shell with a whorl height of $6 \mathrm{~mm}$ and a body chamber length of $13.3 \mathrm{~mm}$. The aperture is open with a well-developed hyponomic sinus. The body chamber reaches about onefourth of the whorl. Eight complete and half of the ninth rib are developed on the body chamber. The fourth to sixth ribs display anomalous growth. The fourth rib is ventrolaterally narrower and ventrally bent towards the apex. The fifth rib disappears ventrolaterally just before the position where the sixth rib bends towards the apex. The shape of the seventh rib is normal. These anomalous ribs correspond to a healed injury.

\section{Discussion}

\section{Embryonic shell}

The embryonic shell of a lechritrochoceratid shows three morphologically discernible growth stages. The first stage is represented by a small elliptical, dorsoventrally elongated cicatrix with a central bar similar to that in Nautilus and fossil nautilids (Schindewolf 1933; Arnold et al. 1987; Tanabe and Uchiyama 1997; Chirat and von Boletzky 2003). The flattened area of the cicatrix is inclined towards the dorsum (P. scharyi sp. nov.). The second stage comprises a rapidly expanding shell; shell shape differs between dorsum and venter; the shell is more curved dorsally ( $P$. scharyi sp. nov.) or ventrally ( $P$. asperum). The most apical part of the shell is thereby roughly hemispherical. The length of this stage is between 2.2 and $3 \mathrm{~mm}$. The third stage starts with a rapid decrease in expansion rate and corresponds to the development of a slightly curved shell forming about two-thirds of the embryonic shell. The ventral side of the shell has a greater curvature than the almost straight dorsal side; the shell thus expanded ventrally. The embryonic shell of $P$. asperum is more curved than in other closely related species. The cross 
Table 1 Dimensions (in millimetres) of lechritrochoceratid embryonic shells, corresponding growth stage, age and source reference

\begin{tabular}{lllllll}
\hline Species & $L$ & $D$ & $L / D$ & Growth stage & Series & References \\
\hline Kosovoceras sandbergeri (Barrande, 1865) & $<4$, c. 5 & 2 & & Adult & Uppermost Ludlow & Turek (1990) \\
Peismoceras pulchrum (Barrande, 1865) & 4.5 & 3 & 1.5 & Adult & Lowermost Ludlow & Turek (1990) \\
Calocyrtoceras cognatum (Barrande, 1866) & 5 & 4 & 1.25 & Juvenile & Uppermost Ludlow & Turek (1990) \\
Peismoceras scharyi sp. nov. & 7.5 & 3.8 & 1.97 & Juvenile & Upper Wenlock & New data \\
Peismoceras asperum (Barrande, 1865), NM L 46908 & 7.5 & 3.4 & 2.21 & Juvenile & Lower Ludlow & New data \\
Peismoceras asperum (Barrande, 1865), NM L 46909 & 6.6 & 2.9 & 2.28 & Early sub-adult & Lower Ludlow & New data
\end{tabular}

$L$ shell length, $D$ shell diameter, $L / D$ ratio of embryonic shell length to maximal diameter

section of the embryonic shell is circular. The maximum shell diameter of the embryonic shell is between 2 and $4 \mathrm{~mm}$, the length is $4.5-7.5 \mathrm{~mm}$ (Table 1). The size of the embryonic shell somewhat differs even between the closely related successive species Peismoceras pulchrum and $P$. asperum. There is an indication of some size variation within P. asperum.

A small depression on the outer shell wall situated near the ventral margin of the cicatrix in P. scharyi sp. nov. was figured by Barrande (1877, pl. 511, figs 13-14). Schindewolf (1933) interpreted this feature as an indication of the initial siphuncle position (see also Shimansky and Zhuravleva 1961; Teichert 1964). Chirat and von Boletzky (2003) considered the depression as the sac-shaped initial portion of the siphuncle. If this interpretation is correct, the caecum of lechritrochoceratids would be located at the dorsal margin of the cicatrix, although the definite siphuncle position in sub-adults and adults is between the centre and the venter.

The embryonic shell sculpture consists of prominent longitudinal lirae, more or less discernible growth lines and eventually transverse ridges. The density of longitudinal lirae varies markedly in Peismoceras species (17-35 per lateral side). Intraspecific variation in the number of lirae is here documented in P. asperum. Lirae appear around the cicatrix as in other nautilids (Arnold et al. 1987; Chirat and von Boletzky 2003) with further lirae in between in the stage of the rapid shell expansion and occasionally also later on the embryonic shell. Ventrolaterally, the lirae slope on the apex towards the venter, forming a flexure in their shape; a similar flexure has also been documented from some other nautilids (Chirat and von Boletzky 2003).

Moderately pronounced transversal growth ridges appear in $P$. asperum already in the embryonic shell at the position where the expansion rate decreases; in other lechritrochoceratid species, growth ridges are not discernible. A small ventral lobe in the transverse growth lines of the second half of the embryonic shell implies the early development of a hyponome in the egg capsule as in modern nautilids (Arnold et al. 1987; Shigeno et al. 2008).

\section{Juvenile stage}

Hatching in lechritrochoceratids is manifested by the appearance of ribs and usually by a change in sculpture and shell curvature (Turek 2010), which is consistent with the data presented herein. The first rib is usually accompanied by an increasing shell diameter or a nepionic constriction followed by a marked elevation (P. scharyi, Fig. 1a-d). Early-hatched specimens (Turek 2010) of Peismoceras exhibit a slightly curved, minute shell with an almost straight dorsum (Table 1). The aperture is open, transverse or slightly oblique to the shell axis, with a well-developed hyponomic sinus. Internal structures of the shell are unknown. The body chamber in hatchlings represented about $40 \%$ of the embryonic shell length. Due to the growth of diagenetic calcite crystals inside the apical parts of the phragmocone, septa and other internal structures are in all known specimens totally destroyed. Therefore, the number of phragmocone chambers in hatchlings can only be estimated. Turek (2010) calculated four or five phragmocone chambers. The embryonic shell of Late Palaeozoic nautiloids usually consist of four to six phragmocone chambers (Ruzhentsev and Shimansky 1954). The shell aperture thus was oriented downwards towards the bottom during life (Ruzhentsev and Shimansky 1954; Shimansky 1967). The length of the embryonic shell of lechritrochoceratids is between 4.5 and $7.5 \mathrm{~mm}$, which was thus the minimum diameter of lechritrochoceratid eggs. In extant cephalopods, eggs of planktic cephalopods have a diameter smaller than $3 \mathrm{~mm}$. Typically, the eggs of nektobenthic cephalopods exceeded $7.5 \mathrm{~mm}$ in diameter (see De Baets et al. 2015). The size of the lechritrochoceratid embryonic shell rather implies demersal hatchlings but a planktic habit cannot be excluded. Pelagic juveniles and planktic and nektic adults commonly co-occur in oxygen deficient environments represented by black shales in the Silurian rocks of the Prague Basin. However, no lechritrochoceratid hatchlings were found in such an association. Although direct evidence for the mode of life of lechritrochoceratid hatchlings is missing, we suggest that a demersal habit 
appears more likely. With the exception of $P$. asperum, which is also known from Wales (Holland 2010), all others species of Peismoceras known from the Prague Basin are endemic, which supports a demersal habit (co-occurring pelagic and nektic cephalopods exhibit a wide biogeographic distribution).

The body chamber of juvenile $P$. asperum occupies about $110^{\circ}-115^{\circ}$ of the whorl and possesses nine ribs. In the early sub-adult specimen, the body chamber possessing 13 ribs represents $140^{\circ}$ of the whorl. The body chamber length thus increases during ontogeny. In fully grown specimens, the body chamber reached about $170^{\circ}$, but the number of ribs (thirteen) corresponds to an early sub-adult stage (Barrande 1865). The shape of the cross section changes within the first whorl from circular to slightly compressed in both studied species. Longitudinal lirae on the early juvenile shell continue from the embryonic shell. A fine reticulate sculpture typical is present in all Peismoceras species on the fourth ( $P$. scharyi sp. nov.) or eighth rib ( $P$. asperum). The biological orientation changed in the course of growth of the first whorl of the juvenile shell like in other lechritrochoceratids (Turek 1975). Except for the early juvenile stage, the aperture of the strongly curved (cyrtoconic) shell was oriented more downwards than in the sub-adult stage with coiled shell (Westermann 1998). The hyponomic sinus was already well developed in juveniles, although its depth increased during the next growth phase, suggesting that it became stronger and thereby, swimming abilities probably improved. The shell form, however, limited active swimming and the hydrodynamic stability of the shell. Thus, the juveniles were most probably demersal swimmers like adults, although their swimming ability was likely more limited (see Turek 1975; Blind 1988; Westermann 1998). When the shell attained one whorl, the cephalopod acquired the characteristic nautilid habit with the aperture oriented obliquely upward.

Three of the four juvenile shells of $P$. asperum exhibit a repaired shell injury (damage of the apertural margin; compare Kröger 2004; Klug 2007); in one specimen (Fig. 2e), a V-shaped shell break caused an anomalous growth of ribs. Repaired injuries recorded a predator attack on juveniles. Juveniles were able to survive and heal even relatively serious shell damage. The characters of shell injuries correspond to that observed in sub-adult and adult shells (Turek and Manda 2010).

\section{Occurrence of juveniles}

From more than 300 adult and sub-adult specimens of Peismoceras examined by Turek (2010), only 1 retained the embryonic shell. The embryonic shell wall is very thin and thus fragile (Fig. 2). As there is no indication of the loss of parts of phragmocone throughout lechritrochoceratid ontogeny, the embryonic shell probably formed an integral part of the shell during the entire life of the animal. The common absence of the embryonic shell in adult and sub-adult fossil specimens (for discussion see Stridsberg 1985 ) is thus most likely related to taphonomic loss before shell burial.

Until now, neither specimen of Peismoceras nor other coiled lechritrochoceratids in which the shell reached less than one whorl had been described. A specimen of Peismoceras in which the shell reached slightly more than one whorl was described from the Wenlock strata of the Carnic Alps (Heritsch 1929; Histon 1999). Juvenile early posthatched stages with a cyrtoconic shell were described in two late Silurian lechritrochoceratid species-Calocyrtoceras cognatum (Barrande, 1866) (Turek 2010; embryonic shell, several phragmocone chambers plus the body chamber) and ?Lechritrochoceras mulus (Barrande, 1965) (Gnoli and Histon 1998; the body chamber plus a part of the phragmocone). The scarce fossil record of hatchlings could be attributed to a low mortality of juveniles, taphonomic loss or, alternatively, ecological causes. Juvenile specimens described here co-occur in facies and faunal associations with adult $P$. asperum. The preservation of embryonic shells was facilitated by the local depositional conditions in which empty shells were deposited in narrow interspaces between coral colonies. Associated complete encrinurid trilobites and articulated nuculid bivalves support temporal quiet water domains in coral colonies interspaces.

The rarity of lechritrochoceratid hatchlings thus appears to be more likely caused by a taphonomic loss of their fragile shells, for example by breakage of the apex in subadult and adult shells. Three of the four studied specimens of $P$. asperum exhibit healed injuries. This may reflect the role of crushing predators responsible for the destruction of fragile parts of shells.

\section{Early shell of lechritrochoceratids and Kionoceras Hyatt, 1884}

Turek (2010) attributed an embryonic shell from the Ludlow Series of Gotland to the lechritrochoceratid Calocyrtoceras cf. simulans (Barrande, 1865). However, he noticed that the specimen also resembles the early shell of the orthoceratoid Kionoceras from which it differs only in having more pronounced ribs and a more curved shell. Newly examined material of Kionoceras (Manda and Turek, unp. data) and the well-preserved apex in $P$. scharyi sp. nov. allow the revision of the specimen determined by Turek (2010) as $C$. cf. simulans. The cicatrix of this specimen is larger and the topmost part of the apex is flat (in lechritrochoceratids, the apex is more convex), the 
cicatrix area is inclined dorsally on the convex side (in lechritrochoceratids, it inclines dorsally on the concave side) - the apex morphology thus exhibits characters of Kionoceras. Moreover, the specimen differs from Calocyrtoceras Foerste, 1936 in having straight, more widely spaced ribs and a circular cross section in contrast to the slightly compressed cross section of Calocyrtoceras. The shell curvature in the specimen determined by Turek (2010) as $C$. cf. simulans may fall within the variability of the early shell of Kionoceras. The ribs in the specimen determined by Turek (2010) as $C$. cf. simulans are more elaborated than in Kionoceras, but the ribs represent a highly variable morphological character in straight-shelled cephalopods. Re-assignment of the specimen studied by Turek (2010) to Kionoceras limits the size range of the embryonic shell (length and diameter) in lechritrochocerids.

Based on accessible data dealing with the early ontogeny of Kionoceras and lechritrochocerids, Dzik (1984) suggested a phyletic link between them. Nevertheless, these cephalopods differ in the type of muscle attachments. Lechritrochoceratids possess a pair of laterally attached retractors, while Kionoceras has retractor muscle scars situated on the dorsal side of the shell-a diagnostic character of orthoceratoids (Mutvei 1957, 2002). The similarity in outer shell morphology, size of the embryonic shell and morphology of early juvenile shells between Kionoceras and lechritrochocerids is striking; both cephalopods usually co-occur in a faunule. A possible convergence may have resulted from competition between juveniles in the food web, which could have also affected the abundance of lechritrochocerids.

\section{Early ontogeny of lechritrochoceratids and later nautilids: comparison}

The embryonic shell of the Middle Devonian nautilid Centroceras Hyatt, 1884, Centroceratina Flower in Flower and Kummel (1950), is moderately curved, with a conical apex and distinct growth lines (the diameter of the shell is $6 \mathrm{~mm}$, length is $10.3 \mathrm{~mm}$; Flower 1952). Hatching is manifested by the appearance of nodes or ventrally suppressed ribs and a sudden change of the shell curvature. The shape of the cross section changed from circular to subquadrate in the early juvenile shell. The embryonic shell of Late Palaeozoic nautilids of the suborder Tainoceratina Shimansky, 1957 is curved or even spirally coiled; the shell represents about one to two-thirds of the whorl. The apex is conical as in Centroceras and the first phragmocone chamber is very short. Growth lines or longitudinal lirae are present. The nepionic constriction, a break in shell curvature or a change in sculpture, is linked with hatching (Ruzhentsev and Shimansky 1954;
Shimansky 1967; Mapes et al. 2007). In the Triassic Tainoceratina, the embryonic shell of some taxa corresponds roughly to the first whorl (e.g. Sobolev 1989; Shigeta and Zakharov 2009).

The early ontogenetic development of Devonian lechritrochocerids is unknown (Dzik and Korn 1992). Embryonic shells of Silurian lechritrochocerids differ from later nautilids in shape; the shell is only slightly curved, the apical part is roughly hemispherical, not pointed and possesses a flattened cicatrix area (the cicatrix is probably also larger). The size of the embryonic shell (diameter, length) in lechritrochocerids is close to its lower size limit in Tainoceratina (see Ruzhentsev and Shimansky 1954). Nevertheless, the diameter and length of the embryonic shell in Tainoceratina (Fig. 4) is usually larger than in lechritrochoceratids. In lechritrochoceratids, considered herein as basal nautilids, the characteristic features are a slightly curved and a slowly expanding embryonic shell, a relatively long phragmocone (with about five phragmocone chambers), a long body chamber, usually a reticulate sculpture, a thin tubular siphuncle, a pair of ventrolaterally situated retractor muscles and a cicatrix with a central bar. Lechritrochoceratid hatchlings even resemble the straightshelled orthoceratoid Kionoceras (Miagkova 1967; Ristedt 1971; own unp. data). However, the fossil record of hatchlings of lechritrochocerids and tainoceratids is very limited (Miller and Thomas 1936; Ruzhentsev and Shimansky 1954; Mapes et al. 2007). A possible benefit of the curved embryonic shell may be the egg-size; the curved shell needs less space than an almost straight shell of the same axis length. In addition to that, a hatchling with a curved juvenile shell (Fig. 4) has different hydrodynamic properties, a different apertural orientation and thus mode of life than a hatchling with a straight shell (see De Baets et al. 2012). The evolutionary pattern of nautilids thus resembles the condition in early ammonoids, in which the earliest taxa possessed a straight embryonic shell inherited from their ancestors, but slightly more derived Early Devonian goniatites already had coiled embryonic shells (De Baets et al. 2012). Goniatitid lineages with an umbilical window became extinct around the early Middle Devonian, whereas only those with a more tightly coiled embryonic shells survived (De Baets et al. 2012). Late Palaeozoic nautilids, however, commonly retained a wide umbilicus similar to lechritrochoceratids (Ruzhentsev and Shimansky 1954; Kummel 1964). Morphological changes throughout the juvenile phase of lechritrochoceratids correspond to a great extent to the shell transformation in tainoceratids, in which this is, however, usually more strongly developed (an increased expansion in the early part of the whorl, a modification of the circular cross section, a change in sculpture and a change from a curved to spirally coiled shell). 

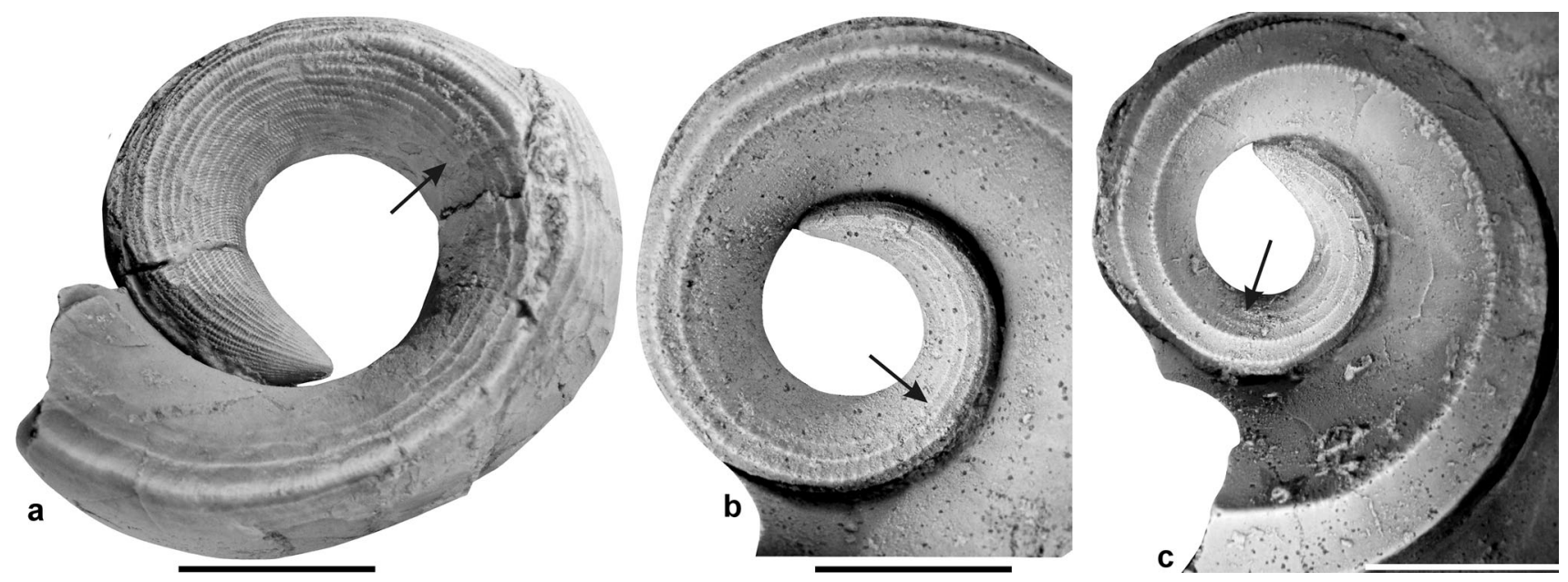

Fig. 4 Embryonic and juvenile shells of some early Mississippian tainoceratids from Belgium. a Vestinautilus sulciferus (Phillips, 1836), a 3360 (type of Koninck 1878, pl. 31, fig. 7), lateral view. b Vestinautilus konincki (Orbigny, 1850), a3350 (type of Koninck

\section{Conclusions}

The embryonic shell of lechritrochocerids consists of three growth stages: (1) a minute elliptical, dorsoventrally elongated cicatrix with a central bar, (2) a short, rapidly expanding part of the shell and (3) a slowly expanding, very slightly curved shell with an almost straight dorsal side. The sculpture of the embryonic shell consists of longitudinal (radial) lirae that appear around the cicatrix. More or less discernible growth lines or transverse ridges appear in some taxa in the third growth stage. The number of lirae differs between individual taxa. A ventral sinus in the ridges indicates that the hyponome had already developed in the egg capsule as in Nautilus (Arnold et al. 1987). Hatching is manifested by the appearance of ribs (in form of a constriction or increasing diameter) and corresponds to the increase in shell curvature. Hatchlings thus acquired slightly curved minute shells (Table 1), which resemble early stages of some straight-shelled cephalopods. Differences in the morphology of the embryonic shell (size, shell curvature and sculpture) have been found in two species of Peismoceras.

The juvenile stage of Peismoceras - considered here as the post-embryonic shell with less than one whorl-is characterised by a prolongation of the body chamber; the circular cross section changed to somewhat compressed or subquadrate. In some taxa, the juvenile shell shape changed from curved to spirally coiled; the expansion rate of the early juvenile shell increased and a fine reticulate ornament appeared on ontogenetically earlier ribs ( $P$. scharyi sp. nov., $P$. asperum). The hyponomic sinus of juveniles is shallower than in sub-adult and adult growth stages.
1878, pl. 30, fig. 1), lateral view. c Vestinautilus cariniferusi (Sowerby, 1824), a3347 (type of Koninck 1878, pl. 28, fig. 5), lateral view. Arrow indicates end of the embryonic shell. Scale bar $1 \mathrm{~cm}$

The juveniles were probably rather demersal animals with a different orientation of the aperture that was more or less directed towards the sea floor. Shell repairs of the same type occur in juvenile specimens as well as in sub-adult and adult shells. The rare occurrence of juvenile shells in the fossil record is probably a result of taphonomic loss before burial; these growth stages are generally missing in subadult to adult specimens.

Slightly curved and post-apically slowly expanding embryonic shells possessing a relatively long phragmocone (with about five phragmocone chambers), a long body chamber representing about $40 \%$ of the embryonic shell length, a usually reticulate sculpture, a thin tubular siphuncle located between centre and venter in the postembryonic shell, a pair of ventrolaterally situated retractor muscles and a dorsoventrally elongated cicatrix with a central bar are characters of basal nautilids of the family Lechritrochoceratidae, assigned to the new suborder Lechritrochoceratina.

\section{Taxononomic appendix}

Order Nautilida Agassiz, 1847

Suborder Lechritrochoceratina new suborder

Diagnosis As for the family Lechritrochoceratidae.

Remarks Dzik (1984) considered the Devonian family Nephriticeratidae Hyatt, 1894, which includes nautiloids with curved or mostly planispirally coiled and relatively rapidly expanding shells, as closely related to the Lechritrochoceratidae. However, ribs-a typical feature of 
lechritrochoceratids - are developed only in some nephriticeratids; in derived forms, they are usually reduced or missing. The siphuncle of nephriticeratids is subcentral, slightly sifted towards the venter or more frequently to the dorsum; the latter position is unknown in lechritrochoceratids (Sweet 1964). The sculpture is reticulate as in lechritrochoceratids or consists of well-developed longitudinal lirae, occasionally combined with longitudinal ribs (Lyrioceras). All nephriticeratids differ from lechritrochoceratids in having a depressed cross section, a narrow hyponomic sinus and a short body chamber representing about one quarter of a whorl (Foerste 1927, 1930a; Sweet 1964).

We assign the five following genera to the family Nephriticeratidae: Baeopleuroceras Williams in Cooper and Williams, 1935, Endoplanoceras Flower, 1938, Lyrioceras Foerste, 1927, Nephriticerina Foerste, 1927 and Triploceras Hyatt, 1884 (compare Sweet 1964). The genera Heracloceras Teichert, 1940 and Rhadinoceras Hyatt, 1894 attributed by Sweet (1964) to this family are in need of revision. The Devonian genus Sphyradoceras Hyatt, 1894, placed in the Nephriticeratidae by Sweet (1964) was transferred by Dzik (1984) to the family Lechritrochoceratidae. The family Nephriticeratidae includes rare and usually poorly known nautiloids; their early ontogenetic development and muscle scars are unknown, which limits their assignment to any nautilid suborder.

Family Lechritrochoceratidae Flower in Flower and Kummel (1950)

Emended diagnosis Planispiral or low trochoceroid shell, dextrally or sinistrally coiled, less frequently cyrtoconic. Oblique sutures form shallow lobes and saddles. Thin tubular siphuncle situated between centre and venter. Distinct ribs appear on the early juvenile shell and persist until maturity; in derived forms, the ribs might be reduced and the mature shell loses ribs close to the aperture. Embryonic shell slightly curved, dorsally almost straight, apex hemispherical, sculpture consisting of well-developed longitudinal (i.e. radial) lirae; transverse sculpture elements differ in individual taxa. Cicatrix minute, inclined dorsally, elliptical in shape with central bar.

Genera included Lechritrochoceras Foerste, 1926; Bickmorites Foerste, 1925; Calocyrtoceras Foerste, 1926; Catyrephoceras Foerste, 1926; Dasbergoceras Dzik and Korn, 1993; Gasconsoceras Foerste, 1936; Inclytoceras Turek, 1976; Kosovoceras Turek, 1975; Leurotrochoceras Foerste, 1926; Magdoceras Turek, 1976; Peismoceras Hyatt, 1894; Savageoceras Foerste, 1930b; Sphyradoceras Hyatt, 1884; Systrophoceras Hyatt, 1894; Trochodyctyoceras Foerste, 1926; ?Jolietoceras Foerste, 1930b.

Genus Peismoceras Hyatt 1894
Type species Trochoceras optatum Barrande, 1865, subsequent designation by Foerste (1926), see Fig. 5.

Emended diagnosis Lechritrochoceratid with planispiral or low-spired dextral or sinistral trochoceroid shell possessing less than two whorls; body chamber divergent. Umbilicus wide with diameter roughly corresponding to shell height at the end of the first whorl. Imprint zone missing or very shallow. Suture with low ventral saddle. Ribs less prominent toward aperture in fully grown specimens, fine reticulate sculpture, longitudinal lirae usually reduced in second whorl, growth lines and ribs form deep V-shaped hyponomic sinus.

Species included Peismoceras optatum (Barrande, 1865), latest Ludlow, Bohemia; P. amicum (Barrande, 1865), early Ludlow, Bohemia; P. asperum (Barrande, 1865), Ludlow, Homerian, scanicus-chimaera Biozone (Kříž 1999; Manda and Krríž 2007), Bohemia, Wales (Blake 1882; Holland 2010); P. bolivianum (Steinmann and Hoek, 1912) comb. nov., middle Silurian, Bolivia; P. carinthiacum (Stache in Heritsch 1929) comb. nov., Wenlock, Carnic Alps (Histon 1999); P. mirandum (Barrande, 1865), late Př́idolí, Bohemia; $P$. pulchrum (Barrande, 1865), early Ludlow, Bohemia (Turek and Manda 2010); P. scharyi sp. nov.; P. subquadratum (Foord, 1891) comb. nov., early Wenlock, Wales; Peismoceras sp., Wenlock, Sheinwoodian, M. belophorus Biozone (unpub. data), Bohemia; Peismoceras sp. nov., Wenlock, Homerian, C. lundgreni Biozone, Bohemia (unpub. data); Peismoceras occurs also in the Wenlock and Ludlow strata of Gotland, the material is deposited in the Museum of Natural History, Stockholm (unp. data).

Peismoceras scharyi sp. nov.

Figures 1, 6, 7

1877 Orthoceras dulce Barrande, 1868; pl. 511, figs 11-14. partim

Types Holotype-C1526 (Fig. 6), Braník locality; paratypes-specimen MCZ 168080 (Fig. 6a, b), MCZ 135441 (Fig. 7c, g), MCZ 159890 (Fig. 7e), MCZ 135487 (Fig. 7f) from the locality Praha-Braník and the specimen NM L 46913 (Fig. 7d, h) from Beroun, Kosov quarry, section no 767 (in Křriž 1992).

Material Types plus one shell with missing apex MCZ 158889 and 40 flattened fragments deposited in the Museum of Comparative Zoology, Harvard.

Name In honour of J. M. Schary, owner of a brewery in Prague and a prominent fossil collector of the late nineteenth century; most of the specimens used herein for the description of the new species originate from his collection. 


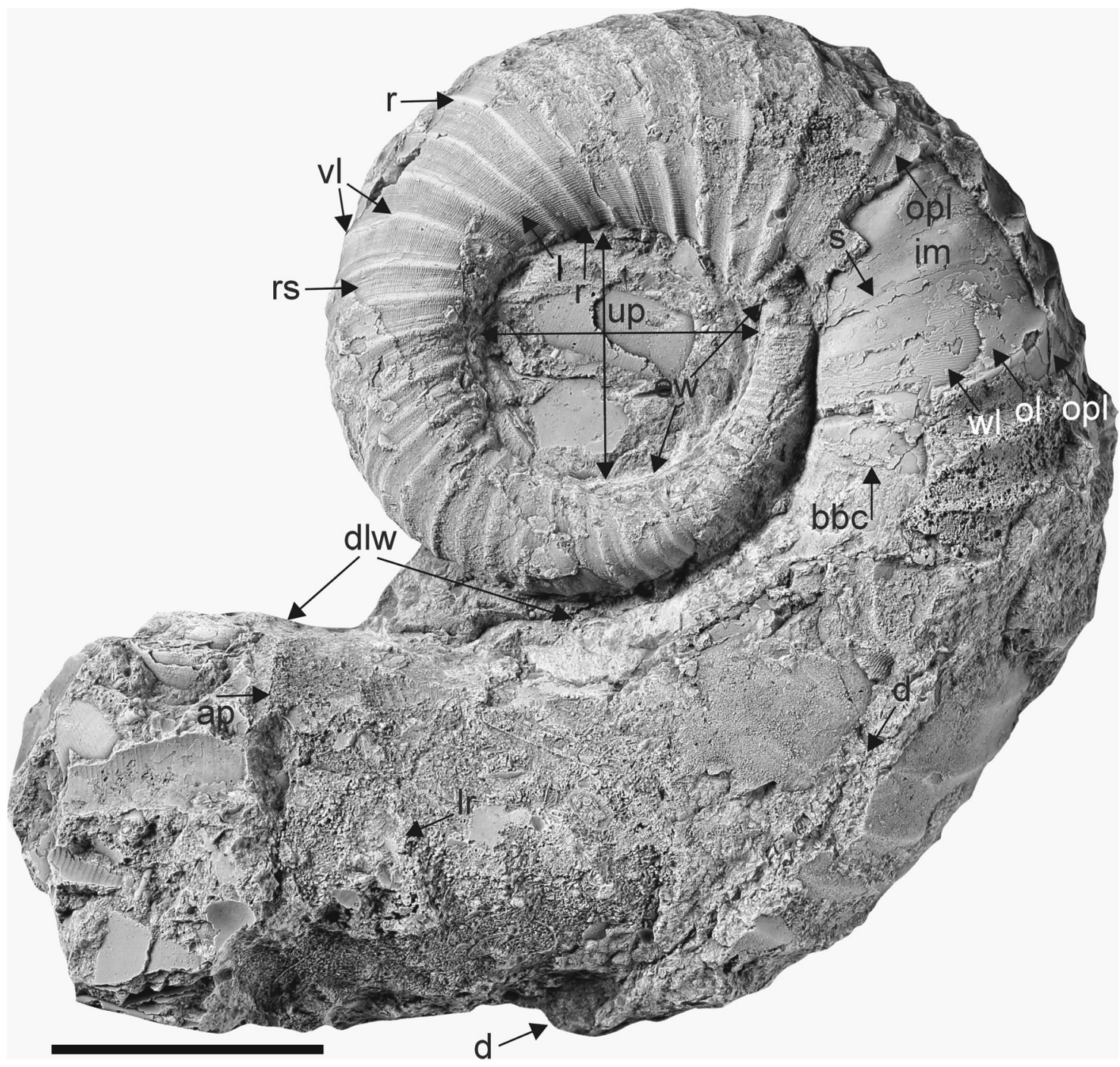

Fig. 5 Peismoceras optatum (Barrande, 1865), left lateral view, lectotype NM-L 8014 (Barrande 1865, pl. 23, figs 6-7; SD Foerste 1936), uppermost Ludlow, Kopanina Formation, Bohemia, PrahaLochkov locality. Specimen clearly shows three shell layers on internal mould wrinkle layer (wl), outer lamella of nacreous layer (ol), outer prismatic layer (opl). Abbreviations: aperture (ap), base of body chamber (bbc), tectonic dislocation (calcite dyke) (d), divergent last whorl (dlw), curved early whorl (ew), internal mould (im), longitudinal lirae (l), last rib (lr), rib (r), reticulate sculpture (rs), suture (s), umbilical perforation (up), ventral lobe of ridges/ribs (hyponomic sinus) (vl); for other abbreviations see Fig. 1. Scale bar $3 \mathrm{~cm}$
Diagnosis Distinctly ribbed species of Peismoceras with curved adapical half of the first whorl, very short divergent adapertural part of the shell, sub-quadrate slightly compressed cross section and subcentral siphuncle, shifted slightly ventrally of centre.

Description Shell tightly coiled with wide umbilicus, first whorl coiled dextrally trochoceroid, exogastric; imprint zone not developed; aperture open and oblique (parallel to ribs). For dimensions see Table 2. Early part of the first whorl is less curved than the following part, regular spiral coiling appears at a shell height of about $8 \mathrm{~mm}$ (Figs. 6a, 7c). Cross section in the early first whorl circular, compressed in later stages (Fig. 7e) with height/width ratio between 1.1 and 1.3. Body chamber relatively short, about $105^{\circ}-130^{\circ}$ of the whorl (Figs. 6a, 7c, f), straight diverging adapertural part of the last whorl is short (in both available specimens, part of the aperture margin is preserved, which excludes taphonomic loss) and only occasionally developed (Fig. 7f, h). Hyponomic sinus broad and deep, sinus width/depth ratio is between 3.2 and 4.8. Phragmocone chambers relatively high, ratio between whorl height (adapertural of the chamber) and chamber length ranges ventrally from 2 to $3.3 ; 2.4$ is the most common value. The 

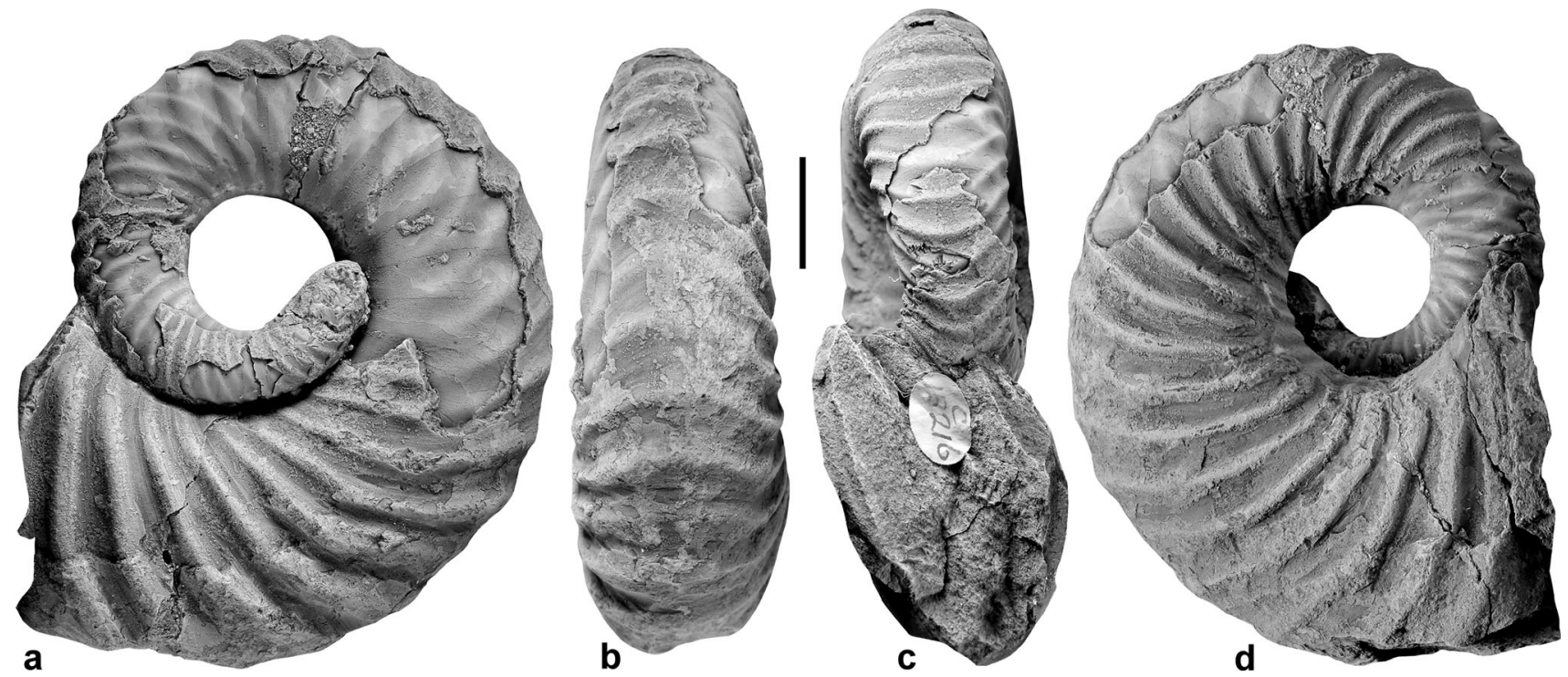

Fig. 6 Peismoceras scharyi sp. nov., holotype C1526, Wenlock, Homerian, P. parvus Biozone, Motol Formation, Praha-Braník locality; left lateral (a), ventral (b), adapertural (c), and right lateral (d) views
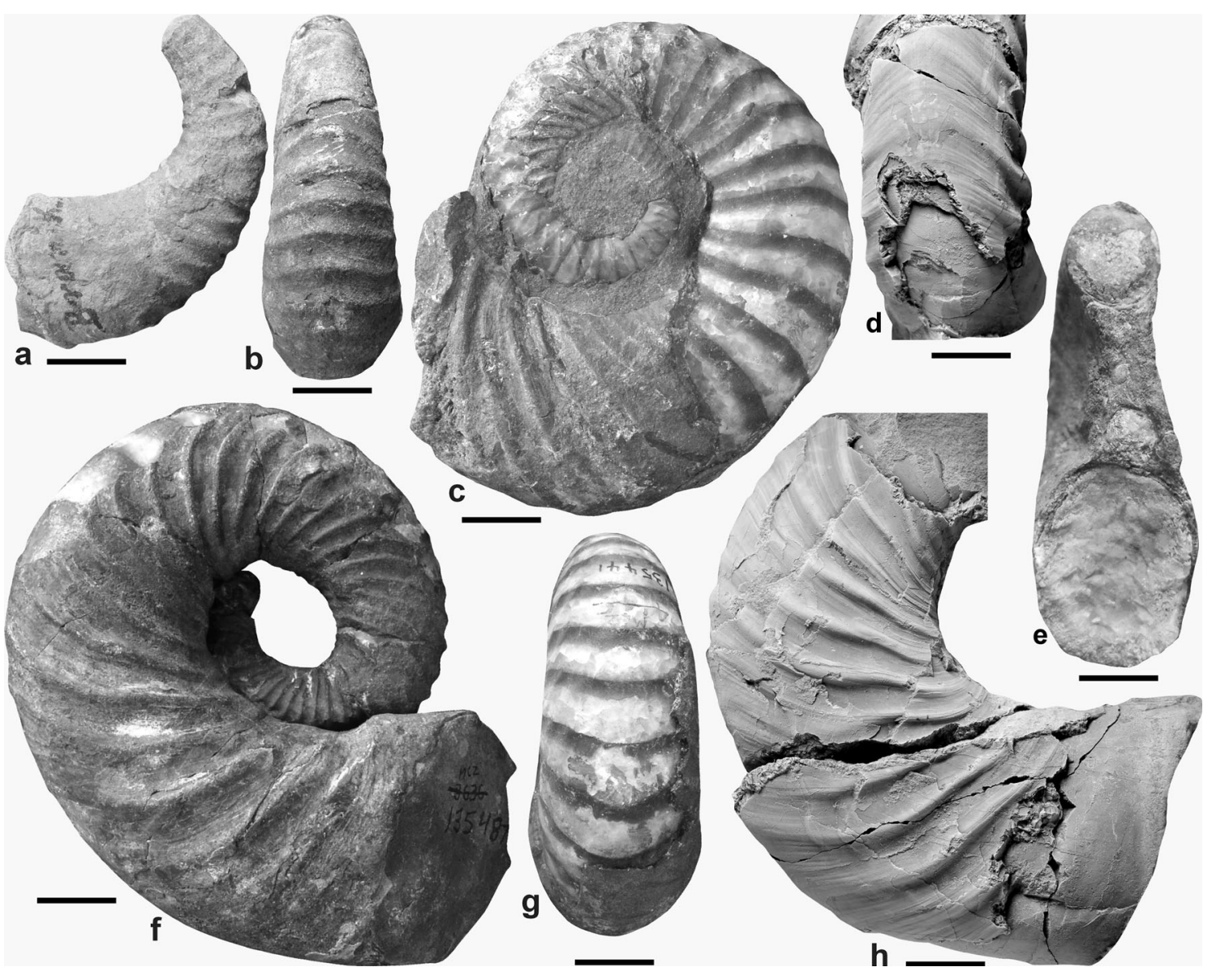

Fig. 7 Peismoceras scharyi sp. nov., paratypes, Wenlock, Homerian, $P$. parvus Biozone, Motol Formation, Praha-Braník locality (a-c, eg) and Kosov Quarry section 767 (d, h). a, b MCZ 168080, lateral and ventral view. c, g MCZ 135441, cross section, lateral and ventral views. d, h NM L 46913, ventral and lateral views. e MCZ 159890, whorl cross section. f MCZ 135487, lateral view. Scale bar equals $1 \mathrm{~cm}$ 
Table 2 Dimensions of $P$. scharyi sp. nov., shell diameter $(D)$, whorl height (WH), whorl width (WW), umbilical diameter (UD), length of divergent last whorl (LP), all in millimetres and body chamber length in degree (BCL)

\begin{tabular}{lllllll}
\hline Specimen & $D$ & WH & WW & UD & LD & BCL \\
\hline MCZ 13587 & 72.7 & $32 . .3$ & a & 11 & 8 & $>170^{\circ}$ \\
MCZ 135441 & 62.1 & 26.9 & 24.3 & 11.8 & - & $105^{\circ}$ \\
MCZ 159889 & 66.8 & 29.3 & a & 15.5 & - & $>160^{\circ}$ \\
C 1526 & 58.5 & 27.2 & 20.5 & 11.4 & - & $130^{\circ}$ \\
NM L 46913 & $<70.9$ & 35 & 26 & - & 9.8 & - \\
\hline
\end{tabular}

${ }^{\mathrm{a}}$ Values not measurable due to flattening

septal distance is about two times higher ventrally than dorsally. Septa moderately concave, mural part ventrally of about one-third of the corresponding chamber length (Fig. 7c). Sutures oblique with a shallow dorsolateral saddle, a ventrolateral lobe and a broad ventral saddle (Fig. 6c, g); the adapical part of the ventrolateral sutural lobe coincides with the appearance of the hyponomic sinus indicated by ribs. Siphuncle circular in cross section (Fig. 7e), subcentral, slightly shifted to the ventral side. Diameter of the septal perforation about $1 / 12$ of whorl height, internal structures of the siphuncle unknown. Ribs are well developed, symmetrical in cross section; about 27 ribs per whorl are present. Ribs are rursiradiate (angle with shell width about $45^{\circ}$ ) forming a broad ventral lobe. Ribs are more distinct laterally then ventrally. Fine reticulate sculpture is well developed in early part of the first whorl (Fig. 7b), then longitudinal lirae are reduced and growth lines become irregular (Fig. 7h).

Remarks Peismoceras scharyi sp. nov. resembles P. optatum in the mode of shell coiling and well elaborated ribs, from which it differs in having a compressed cross section in later growth stages, the siphuncle is slightly shifted towards the venter and a very short divergent last whorl $(P$. optatum exhibits sub-circular cross section, subventral/ ventral siphuncle and a relatively long uncoiled part of the last whorl).

Juvenile shell described here was originally assigned by Barrande (1877, pl. 511, Figs. 11-14) to the species Orthoceras dulce Barrande, 1868. Three specimens of Orthoceras dulce illustrated by Barrande $(1868,1877)$ belong in fact to different taxa. Two juvenile shells (Barrande 1868 , pl. 295, fig. 16-18; 1877, pl. 488, box 5) are assigned herein to the genus Cyrtocycloceras and it differs from the specimen illustrated by Barrande (1868) on pl. 511, figs 11-14 in having a smaller diameter (by one half), a spherical apex, straight ribs and no radial lines (see Ristedt 1968; Dzik 1984). By contrast, MCZ 163512 (Barrande 1868, pl. 511, figs 11-14) shows all of the typical characters of an embryonic and juvenile shell of a lechritrochocerid (Turek 2010). Only P. scharyi sp. nov. occurs in the late Homerian strata of Bohemia, where also the studied juvenile specimen was found. Early part of the first whorl of $P$. scharyi sp. nov. is moderately curved and the hyponomic sinus is relatively shallow, which supports the assignment of the specimen to $P$. scharyi sp. nov.

Occurrence Wenlock, Homerian, P. parvus Biozone; Motol Formation. Bohemia, Teplá-Barrandian Terrain, Prague Synform; Kosov Quarry, section767; old localities Kozel and Branik.

Acknowledgements Strategic Research Plan of the Czech Geological Survey (Project no. 338800), Czech Grant Agency 14-16124S (SM) and Ministry of Culture project DKRVO 2018/06 (VT) supported the research. The authors thank Jessica Cundiff (Museum of Comparative Zoology, Harvard) for access to collections and her kind assistance during our stay, Z. Hughes (Natural History Museum London) for the loan of a studied specimen, M. Kubajko for the highly skilled preparation of specimens of $P$. asperum, M. Aubrechtová (Prague) for critically reading the manuscript and for improving its English. The reviewer comments by A. Pohl (Zürich) and B. Kröger (Helsinki) were important for the final form of the manuscript.

\section{References}

Agassiz, L. (1847). An introduction to the study of Natural history, in a series of lectures delivered in the hall of the College of Physicians and Surgeons. New York: Greeley \& McElrath.

Arnold, J. M., Landman, N. H., \& Mutvei, H. (1987). Development of the embryonic shell of Nautilus. In W. B. Saunders \& N. H. E. Landman (Eds.), Nautilus. The biology and paleobiology of a living fossil (pp. 373-400). Dordrecht: Springer.

Barrande, J. (1865-1877). Systeme Silurien du centre de la Boheme, I $^{\text {ere }}$ partie: Recherches Paléontologiques, Vol. II, Classe de Mollusques, Ordre des Céphalopodes. 1865, ser. 6, pls 1-107; 1866 , ser. 7 , pls $108-244 ; 1867$, ser. $1 ; 1868$, ser. 8, pls 245-350; 1870 , ser. 2 , ser. 9 , pls $351-460 ; 1874$, ser. $3 ; 1877$, ser. 4 , ser. 5 , supplement 1, supplement 2, pls 461-544. Prague and Paris: Published by the author.

Blake, J. F. (1882). A monograph of the British fossil Cephalopoda, part I, introduction and Silurian species. London: John Van Voorst.

Blind, W. (1988). Comparative investigations on the shell morphology and structure of Nautilus pompilius, Orthoceras sp., Pseudorthoceras sp., and Kinoceras sp. In J. Widemann, \& J. Kullmann (Eds.), Second international cephalopod symposium. Cephalopods present and past (pp. 273-289). Stuttgart: Schweizerbart'sche Verlagsbuchlhandlung.

Bouček, B. (1937). Stratigrafie siluru v dalejském údolí u Prahy a v jeho nejbližším okolí. Rozpravy II. Trúdy České Akademie, 46, $1-20$.

Chirat, R., \& von Boletzky, S. (2003). Morphogenetic significance of the conchal furrow in nautiloids: Evidence from early embryonic shell development of Jurassic Nautilida. Lethaia, 36, 161-170.

Cooper, G. A., \& Williams, J. S. (1935). Tully formation of New York. Bulletin of the Geological Society of America, 46, 781-868.

De Baets, K., Klug, C., Korn, D., \& Landman, N. H. (2012). Early evolutionary trends in ammonoid embryonic development. Evolution, 66, 1788-1806. 
De Baets, K., Landman, N. H., \& Tanabe, K. (2015). Ammonoid embryonic development. In C. Klug, D. Korn, K. De Baets, I. Kruta, \& R. H. Mapes (Eds.), Ammonoid paleobiology: From anatomy to ecology (pp. 113-205). Dordrecht: Springer.

Deecke, W. (1913). Paläontologische Betrachtungen. I. Über Cephalopoden. Neues Jahrbuch für Mineralogie, Geologie und Paläontologie, Beilageband, 35, 241-276.

Dzik, J. (1984). Phylogeny of the Nautiloidea. Palaeontologia Polonica, 45, 1-219.

Dzik, J., \& Korn, D. (1992). Devonian ancestors of Nautilus. Paläontologische Zeitschrift, 66, 81-98.

Flower, R. H. (1938). Devonian brevicones of New York and adjacent areas. Palaeontographica Americana, 2, 1-84.

Flower, R. H. (1952). The ontogeny of Centroceras with remarks on the phylogeny of the Centroceratidae. Journal of Paleontology, 26, 519-528.

Flower, R. H. (1955). Saltations in nautiloid coiling. Evolution, 9, 244-260.

Flower, R. H. (1964). Nautiloid shell morphology. Memoir New Mexico Institute Mining Technology, 13, 1-79.

Flower, R. H., \& Kummel, B. (1950). A classification of the Nautiloidea. Journal of Paleontology, 24, 603-616.

Foerste, A. F. (1925). Notes on cephalopod genera, chiefly coiled Silurian forms. Denison University Bulletin, Journal of the Scientific Laboratories, 21, 1-69.

Foerste, A. F. (1926). Actinosiphonate, Trochoceroid and other cephalopods. Denison University Bulletin, Journal of the Scientific Laboratories, 21, 285-383.

Foerste, A. F. (1927). Devonian cephalopods from Alpena in Michigan. Contributions from the Museum of Geology University of Michigan, 2, 189-208.

Foerste, A. F. (1930a). Additional notes on Nephriticerina. University of Michigan, Museum of Paleontology Contributions, 3, 151-154.

Foerste, A. F. (1930b). Port Byron and other Silurian cephalopods. Denison University Bulletin, Journal of the Scientific Laboratories, 23, 1-110.

Foerste, A. F. (1936). Silurian cephalopods of the Port Daniel area on Gaspe Peninsula, Eastern Canada. Denison University Bulletin, Journal of the Scientific Laboratories, 31, 21-92.

Foord, A. H. (1891). Catalogue of the fossil Cephalopoda in the British museum (natural history), part 2. London: British Museum of Natural History.

Gnoli, M., \& Histon, K. (1998). Silurian nautiloid cephalopods from the Carnic Alps: A preliminary investigation. Bollettino della Società Paleontologica Italiana, 36, 311-330.

Havlíček, V. (1995). New data on the distribution of brachiopods in the Motol and lowest Kopanina Formations (Wenlock, lower Ludlow, Prague Basin, Bohemia). Věstnık Čského geologického ústavu, 70, 47-63.

Havlíček, V., \& Štorch, P. (1990). Silurian brachiopods and benthic communities in the Prague Basin (Czechoslovakia). Rozpravy Ústrédniho ústavu geologického, 48, 1-275.

Heritsch, F. (1929). Faunen aus dem Silur der Ostalpen. Abhandlungen der Geologischen Bundesanstalt, 23, 1-181.

Histon, K. (1999). Revision of the Silurian nautiloid cephalopods from the Carnic Alps (Austria)—The Heritsch (1929) collection in the Geological Survey of Austria. Abhandlungen der Geologischen Bundesanstalt, 56, 229-258.

Holland, C. H. (2010). Coiled nautiloid cephalopods from the British Silurian. Proceedings of the Geologists' Association, 121, 13-23.

Hyatt, A. (1883-1884). Genera of fossil cephalopods. Boston Society Natural History Proceedings, 22, 273-338.

Hyatt, A. (1894). Phylogeny of an acquired characteristic. American Philosophical Society Proceeding, 32, 349-647.
Klug, C. (2007). Sublethal injuries in Early Devonian cephalopod shells from Morocco. Acta Palaeontologica Polonica, 52, 749-759.

Klug, C., Meyer, E. P., Richter, U., \& Korn, D. (2008). Soft-tissue imprints in fossil and Recent cephalopod septa and septum formation. Lethaia, 41, 477-492.

Kobluk, D. R., \& Mapes, R. H. (1989). The fossil record, function and possible origins of shell color Patterns in Paleozoic Marine invertebrates. Palaios, 4, 63-85.

Koninck, L. G. (1878). Faune de calcaire carbonifère de la Belgique, 1e partie, Poissons et le genre Nautile. Annales du Musée Royal d'Histoire naturelle de Belgique, 2, 1-152.

Kř́iž, J. (1991). The Silurian of the Prague Basin (Bohemia) - tectonic, eustatic and volcanic controls on facies and faunal development. Special Papers in Palaeontology, 44, 179-203.

Kříž, J. (1992). Silurian Field Excursions: Prague Basin (Barrandian), Bohemia. National Museum Wales, Geological Series, 13, $1-111$.

Kříž, J. (1998). Silurian. In I. Chlupáč, V. Havlíček, J. Kříž, Z. Kukal, \& P. Štorch (Eds.), Paleozoic of the Barrandian (Cambrian to Devonian) (pp. 79-101). Praha: Český geologický ústav.

Kříž, J. (1999). Cephalopod limestone biofacies on the northern slopes of the Silurian volcanic archipelago in the Prague Basin containing re-described benthic Cardiola donigala-Slava cubicula Community (Bivalvia, Barrandian, Bohemia). Journal of the Czech Geological Society, 44, 159-165.

Kříž, J., Dufka, P., Jaeger, H., \& Schönlaub, H. P. (1993). The Wenlock/Ludlow Boundary in the Prague Basin (Bohemia). Jahrbuch der Geologischen Bundesanstalt, 136, 809-839.

Kröger, B. (2004). Large shell injuries in Middle Ordovician Orthocerida (Nautiloidea, Cephalopoda). GFF, 126, 311-316.

Kummel, B. (1964). Nautiloidea-Nautilida. In R. C. Moore (Ed.), Treatise on Invertebrate Paleontology, Part K, Mollusca 3 (pp. 383-466). Lawrence: The University of Kansas Press.

Manda, Š., \& Kříž, J. (2007). New cephalopod limestone horizon in the Ludlow (Gorstian, early L. scanicus Zone) of the Prague Basin (Bohemia, Perunica). Bollettino della Societá Paleontologica Italiana, 46, 33-45.

Manda, Š., \& Turek, V. (2011). Late Emsian Rutoceratoidea (Nautiloidea) from the Prague Basin, Czech Republic: Morphology, diversity and palaecology. Palaeontology, 54, 999-1024.

Mapes, R. H., Niko, S., Frýda, J., \& Nutzel, A. (2007). A newly hatched coiled nautiloid from the Permian of Italy. Journal od Paleontology, 81, 1118-1121.

Miagkova, E. I. (1967). Silurian nautiloids of the Siberian platform. Moscow: Nauka. [in Russian].

Miller, A. K., \& Thomas, H. D. (1936). The Casper Formation (Pennsylvanian) of Wyoming and its Cephalopod Fauna. Journal of Paleontology, 10, 715-738.

Mutvei, H. (1957). On the relations of the principal muscles to the shell in Nautilus and some fossil nautiloids. Arkiv Mineralogy and Geology, 2, 219-254.

Mutvei, H. (2002). Nautiloid systematics based on siphuncular structure and position of muscle scars. Abhandlungen der Geologischen Bundesanstalt, 57, 379-392.

Orbigny, A. D. (1850). Prodrome de Paléontologie stratigraphique universelle des animaux mollusques et rayonées faisant suite au cours élémentaire de paléontologie et géologie stratigraphique, vol. I. Paris: privately published.

Phillips, J. (1836). Illustrations of the geology of Yorkshire; or a description of the strata and the organic remains; accompanied by a geological map, sections, and diagrams, and figures of the fossils, part 2. The Mountain Limestone District. London: John Murray. 
Raumer, J., \& Stampfli, G. (2008). The birth of the Rheic OceanEarly Paleozoic subsidence patterns and subsequent tectonic plate scenarios. Tectonophysics, 461, 9-20.

Ristedt, H. (1971). Zum Bau der orthoceriden Cephalopoden. Palaeontographica Abteilung A, 137, 155-195.

Robardet, M. (2003). The Armorica microplate: Fact or fiction? Critical review of the concept and contradictory palaeobiogeographical data. Palaeogeography, Palaeoclimatology, Palaeoecology, 195, 25-148.

Ruzhentsev, V. E., \& Shimansky, V. N. (1954). Lower Permian coiled and curved nautiloids of the southern Urals. Transactions of the Paleontological Institute, 50, 1-152. (In Russian).

Schindewolf, O. H. (1933). Vergleichende Morphologie und Phylogenie der Anfangskammern tetrabranchiater CephalopodenEine Studie über Herkunft, Stammesentwicklung und System der niederen Ammonoideen. Abhandlungen der Preusischen Geologischen Landesanstalt, Neue Folge, 148, 1-115.

Shigeno, S., Sasaki, T., Moritaki, T., Kasugai, T., Vecchione, M., \& Agata, K. (2008). Evolution of the cephalopod head complex by assembly of multiple molluscan body parts: Evidence from Nautilus embryonic development. Journal of Morphology, 269, $1-17$.

Shigeta, Y., \& Zakharov, Y. D. (2009). Cephalopods. In Y. Shigeta, Y. D. Zakharov, \& H. Maeda (Eds), The Lower Triassic system in the Abrek Bay area, south Primorye, Russia. National Museum of Nature and Science Monographs, 38, 44-140.

Shimansky, V. N. (1957). Taxonomy and phylogeny of the order Nautilida. Byulletin Moskovskogo obshchestva Ispytately Prirody, Otdel Geologicheskiy, 32, 105-120. (in Russian).

Shimansky, V. N. (1967). Carboniferous Nautilida. Transactions of the Paleontological Institute, 115, 1-258. (in Russian).

Shimansky, V. N., \& Zhuravleva, F. A. (1961). Fundamental questions of the systematics of the nautiloids and the relationship of this group. Trudy Paleontologitscheskogo Instituta Akademii Nauk, 90, 1-175. (In Russian).

Šnajdr, M. (1983). New Silurian trilobites from Bohemia. Věstnık Ústředniho Ústavu Geologického, 58, 175-178.

Sobolev, E. S. (1989). Triassic nautiloids of northeastern Asia. Novosibirsk: Nauka. (in Russian).

Sowerby, J. (1824). The Mineral Conchology of Great Britain; or Coloured Figures and Descriptions of those Remains of Testaceous Animals or Shells which have been Preserved at Various Times and Depths in the Earth. continued by James de Carle Sowerby, volume 5. London: published privately.

Stampfli, G. M., von Raumer, J., \& Borel, G. D. (2002). Paleozoic evolution of pre-Variscan terranes: From Gondwana to the Variscan collision. Special Papers Geological Society of America, 364, 263-280.

Stearn, C. W. (1956). Stratigraphy and Paleontology of the Interlake Group and Stonewall Formation of southern Manitoba. Memoir of the Canadian Geological Survey, 281, 1-162.

Steinmann, G., \& Hoek, H. (1912). Das Silur und Kambrium des Hochlandes von Bolivia und ihre Fauna. Neues Jahrbuch für
Mineralogie, Geologie und Paläontologie, Beilage-Band, 34, 176-252.

Storch, P. (1994). Graptolite biostratigraphy of the Lower Silurian (Llandovery and Wenlock) of Bohemia. Geological Journal, 29, 137-165.

Štorch, P., Manda, Š., \& Loydell, D. K. (2014). The early Ludfordian leintwardinensis graptolite Event and the Gorstian-Ludfordian boundary in Bohemia (Silurian, Czech Republic). Palaeontology, 57, 1003-1043.

Sweet, W. C. (1964). Nautiloidea-Barrandeocerida. In R. C. Moore (Ed.), Treatise on Invertebrate Paleontology, Part K, Mollusca 3 (pp. K368-K382). Lawrence: The Geological Society of America.

Tanabe, K., \& Uchiyama, K. (1997). Development of the embryonic shell structure in Nautilus. The Veliger, 40, 203-215.

Teichert, C. (1940). Contributions to Nautiloid nomenclature. Journal of Paleontology, 14, 590-597.

Teichert, C. (1964). Morphology of hard parts. In R. C. Moore (Ed.), Treatise on Invertebrate Paleontology, Part K, Mollusca 3 (pp. 13-53). Lawrence: The Geological Society of America.

Torsvik, T. H., \& Cocks, L. R. M. (2013). New global palaeographical reconstructions for the Early Palaeozoic and their generation. Geological Society, London, Memoirs, 38, 5-24.

Turek, V. (1975). Genus Kosovoceras gen. n. in the Silurian of Central Bohemia. Sbornik geologických věd, Paleontologie, 17, $7-42$.

Turek, V. (1976). Magdoceras gen. n. and Inclytoceras gen. n. from the Silurian of Central Bohemia (Nautiloidea, Barrandeoceratida). Časopis pro mineralogii a geologii, 21, 137-145.

Turek, V. (1987). On some epizoans of mollusc shells from the Upper Silurian (Pridoli) of the Barrandian area. Věstnık Ústrednıho Ústavu geologického, 62, 105-111.

Turek, V. (2007). Systematic position and variability of the Devonian nautiloids Hercoceras and Ptenoceras from the Prague Basin (Czech Republic). Bulletin of Geosciences, 82, 1-10.

Turek, V. (2010). Embryonic shells in some lechritrochoceratids (Nautiloidea, Barrandeocerina). In K. Tanabe, Y. Shigeta, T. Sasaki, \& H. Hirano (Eds.), Cephalopods-Present and past (pp. 85-92). Tokyo: Tokai University Press.

Turek, V., \& Manda, Š. (2010). Variability of colour pattern and shell malformations in Silurian nautiloid Peismoceras Hyatt, 1884. Journal of the National Museum, Natural History, 179, 171-178.

Turek, V., \& Manda, Š. (2011). Colour pattern polymorphism in Silurian nautiloid Phragmoceras Broderip, 1839. Bulletin of Geosciences, 86, 91-105.

Westermann, G. E. G. (1998). Life habits of nautiloids. In E. Savazzi (Ed.), Functional morphology of the invertebrate skeleton (pp. 263-298). London: John Wiley.

Young, R. E., \& Harman, R. F. (1988). "Larva", "paralarva" and "subadult" in cephalopod terminology. Malacologia, 29, 201-207. 